|Araştırma Makalesi / Research Article |

\title{
Gazetelerin Olumlu veya Olumsuz İ̧̧eriklerini, Eleştirel Medya Okuryazarlığı Anlayışıyla Çözümleme
}

\section{Analyzing Positive or Negative Content of Newspapers with Critical Media Literacy Approach}

\section{Mehmet Ülker ${ }^{1}$}

\author{
Anahtar Kelimeler \\ eleştirel içerik analizi \\ medya okuryazarlığı \\ gazete \\ Güney Afrika \\ Cumhuriyeti eğitim \\ sistemi
}

Keywords
critical content analysis
media literacy
newspaper
South African education
system

Başvuru Tarihi/Received

20.12.2018

Kabul Tarihi /Accepted

25.11.2019
Öz

Bu çalışmanın amacı gazetelerdeki olumlu veya olumsuz içerikleri, eleştirel medya okuryazarlığı anlayışına göre çözümleyip tespit etmektir. Nitel temelli bir çalışmadır. Çalışmanın nesnesi, alandaki çalışmalar ve Güney Afrika Cumhuriyetinde İngilizce dilinde yayınlanan gazetelerdir. Çalışma konusu ise yüz yirmi çalışma nesnesi iç̧inde, eğitim sistemini konu etmiş on sekiz gazete içeriğidir. Çalışma konuları: The Star, The Times, The Citizen, The Pretoria News, City Press, The NewAge ve Newspaper adlı gazetelerden alınmışır. Veriler doküman analizi yöntemiyle derlenmiştir. Doküman analizi yöntemiyle elde edilen veriler içerik analizi yöntemiyle ve araştırmacının geliştirdiği formla çözümlenmiş ve bulgular elde edilmiştir. Elde edilen veriler, ihtiyaç duyulduğunda, alandaki çalışmalarla da desteklenerek betimlenmiştir. Bu betimlemelerle; gazetelerdeki medya mesajlarının, eleştirel medya okuryazarlığı anlayışına göre olumlu veya olumsuz olma durumu, tartışmalarla ortaya konmuştur. Çalışma sonuçlarına göre on sekiz çalışma konusunun, on üçü bilgilendirme yapan olumlu medya içeriği sunduğu sonucuna ulaşılmıştır. Beş çalışma konusunun ise olumsuz medya içeriği sunduğu sonucuna ulaşıımışıı. Olumsuz medya içeriğinin: tekrar, güçlü değerlere gönderme, slogan, yanlı, ırk ve sınıf ayrımını destekleme, nefret ve şiddet öğeli, yanlı, propaganda amaçlı ve manipüle edilmiş kavramlar etrafında toplandığı saptanmıştır. Çalışmada kullanılan yolun ve araştırmacının geliştirdiği formun, başka çalışmaların ve sınıf içi uygulamaların özgün şartlarına uyarlanarak kullanılması önerilmektedir.

\section{Abstract}

The aim of this study is to analyze the positive or negative contents of the newspapers according to the critical media literacy understanding. This is a qualitative study. The object of the study is the newspapers published in the English language in the Republic of South Africa. The subject of the study is the eighteen newspapers that have covered the education system among one hundred and twenty study objects. The research items have been taken from the following newspapers: The Star, The Times, The Citizen, The Pretoria News, City Press, The NewAge and Newspaper. The data was collected via document analyzed. The data obtained through document analyzed were analyzed by content analysis method and media literacy content - theme and form developed by the researcher. The data obtained were supported by studies in the field when needed. In this description process; The positive and negative status of the media messages in the newspaper has been demonstrated through discussions according to the critical media literacy understanding. According to the results of the study, it was concluded that thirteen of the eighteen study subjects have been informative and provided positive media content while negative media content was presented in five studies. Negative media contents are gathered around concepts such as sending back to strong values, slogan, biased, supporting racial and class distinction, biased, hateful and violent, propaganda purposes and manipulated concepts. It is suggested that the path used in the study and the form developed by the researcher should be adapted to both classroom practices and teaching in media literacy teaching.

1 Yunus Emre Enstitüsü, Priştine Yunus Emre Enstisüsü, Priştine-KOSOVA; https://orcid.org/ 0000-0002-9072-8868 
Extended Abstract

\section{Introduction}

The study was started by explaining the definitions of media, media channels and the characteristics of the newspaper in different aspects. Afterwards, within the scope of the study the theoretical framework of some concepts is given. These included media literacy, positive and negative media content. Positive media content has been explained around the concepts of grounding, learning, entertainment and socialization. On the other hand, negative media content has been undertaken according to the agenda-building effort rather than the agenda-setting effort. Deficiencies and failures in the media literacy teaching process were also revealed. These failures and deficiencies are explained based on the data obtained in the document analyzed which is based around the process of media literacy, especially from in-class activities, the course conduction and in-class practices. The importance and purpose of the study were determined according to this theoretical framework and explanations. In this context, it is important to contribute to the field with an original work that will diversify and enrich the practices in the field and prioritize different media channels in this context, which will analyze media contents in accordance with critical media literacy understanding.

\section{Method}

Purpose of the study: The aim of this study is to analyze and identify positive or negative messages in newspapers according to critical media literacy. This is a qualitative study. The data was collected via document analyz and media literacy content - theme and form. The data obtained through document analyz were analyzed by content analysis method. With these descriptions, it was investigated whether the study subjects included positive or negative media messages. The object of the study is 120 newspapers published in English in the Republic of South Africa. The subject of the study is 18 newspapers related to the education system in the study objects. The study subjects have been taken from the following newspapers: The Star, The Times, The Citizen, The Pretoria News, City Press, The NewAge and Newspaper.

\section{Result and Discussion}

When the data of the study subject was analyzed by content analysis, findings were obtained in four categories. These are university student actions, metric exam results, information technology-based projects and other topics. These categories and summary contents of the study subjects were included in the tables. The study subjects; In order to describe media literacy in accordance with its understanding, data were recorded on the form developed by the researcher. These data have been handled as a whole with content analysis and studies in the field and they have been described with a critical media literacy understanding. The following findings were reached in these descriptions: All content except the university student actions category has been found to be on the inner pages, pages related to the section, theme or region title. Usually news form was used and sometimes analysis and opinion column form was used. In addition, almost all of the study topics include analysis and research content. The text in the title and content is written in lower case. In order to strengthen the emphasis, some contents included photographs. Albeit limited, colored accent and texture are used. Newspapers are painted in color. The limited eight-page content given in the annex includes graphics and tables.

When the contents of the newspapers were analyzed: it was established that the content of the thirteen out of the eighteen newspapers was found to be neutral, free of prejudice in relation to the general dimension of education system and in the form of news, analysis and columns; it was seen that there were ideas and rich comments. For these reasons, these contents; In one aspect, are described as a media message that directs the education system, ensures its proper functioning and supports the social system. This led to the conclusion that these thirteen contents are positive media content. In addition to this, it has been evaluated that five of the study subjects collected in the category of university student actions; can be related to concepts such as reference to strong values, slogan, biased, supporting racial and class distinction, hate and violence, propaganda and manipulated concepts. An additional study was conducted to describe these evaluations in a way to show the results of the study. This study covers the content and the concepts and issues that are subject to negative media message in these contents gathered around \#..... mustfall theme in the student actions category. Using these data, it is concluded that these five study subjects are negative media content, taking into account the records of the researcher's form.

According to the results of the study, the contents related to the education system, which was the subject of newspaper contents, was collected in four categories. These are; university student actions, metric exam results, information technologybased projects and other topics. Thirteen of the study subjects have positive media content. In addition, the five study topics collected in the category of university student actions have negative media content.

The form developed by the researcher and the way of collecting, analyzing and describing the data used in the study is considered to be original. It has been evaluated that by adapting to the scope of the study to be carried out this form of data collection, analysis and description can be used in different studies and it will also contribute to the conduct of original studies. In this respect, it is recommended to be used both in classroom practices in media literacy teaching and in field studies. 
Giriş

Medya; değişik mecraları olan şemsiye bir kavramın genel adıdır. TV, bilgisayar, radyo, dergi, gazete, reklam-duyuru tahtası (billboard), film, video oyunu, müzik, CD-ROM, DVD, çağrı cihazı, cep telefonu, interaktif kitap gibi teknolojik araçların her birine medya mecrası ve bu medya mecraların hepsine bir bütün olarak da medya denir. Gazete bu açıklamada yer aldığı gibi medya mecralarından biridir. Gazetenin hedef kitlesi okuyucularıdır. Gazeteler okuyucularına yazılı, görsel ve işitsel içerikli mesajlarla iletişim ve etkileşim kurar. Gazete içeriklerinde; haber, spor, ekonomi, siyaset, dış politika, bulmaca, magazin, araştırma, köşe yazısı, analiz, reklam ve yazı dizisi gibi konu ve başlıklar yer bulur. Medya mecrası içinde tercih edilme önceliğine bakıldığında gazete; \%49 oranla takip edilen TV'den hemen sonra \%15,6 oranla ikinci sırada yer alır. Gazete, geçmişte basılı biçimiyle okuyucusuna ulaşırken, teknolojik değişimle birlikte bir dönüşüm yaşamış ve yavaş yavaş internet gazetesi adı da verilen elektronik biçimiyle okuyucuya ulaşmaya başlamıştır. Internet gazetesi, son zamanlarda basılı gazetelere göre daha çok tercih edilir olmuş hatta neredeyse basılı gazeteleri ortadan kaldıracak noktaya gelmiştir. Gazeteler sınıflandırma biçimlerinden biride hedef kitlesidir. Buna göre gazete "fikir ve kitle gazetesi" (Demirkent, 2003, s.43) adlarıyla da sınıflandırılır. Bunun dışında yayın alanı bakımından; şehir, bölge, ulusal ve uluslararası gazete adlarıyla da sınıflandırılır.

Gazetenin okunma gerekçesi Toruk'un (2008) çalışmasına göre \%79,5 oranla bilgilenme ve öğrenme, \%8 oranla eğlenme ve \%6,3 oranla sosyalleşmek içindir. Medya okuryazarlığı bakış açısıyla, bu özelliklerin medyanın olumlu yanı ile ilişkili özellikler olduğu söylenebilir. Bu olumlu özellikler dışında medya içeriklerinde olumsuz özellikler de yer bulabilir. Medya içeriklerindeki olumsuz özellikler, medya içeriğinin gündemi belirleme yerine, gündem oluşturmak için hazırlanmasıyla ilişkilidir. Medya içeriklerinin, birey ve toplumun beklentisi ve amacına hizmet etmek yerine hazırlayan veya hazırlatanların beklenti ve amacına hizmet edecek şekilde veya Bilici'nin (2014, s.211)'de ele aldığı gibi medya içeriğinin ekonomik sebep ile ideolojik ve politik gücün etkisiyle hazırlanması anlaşılır. Olumsuz medya içerikleri açıklanırken birçok kavram kullanılır. Bunlar arasında; ekonomik ve ideolojik beklenti, “lobi faaliyeti, medyada yer alabilmek için olay yaratma ve hükümetin yasal gerekçelerle yaptığı baskılar” (Yüksel, 2001, s.70-73) yer alır. Bu kavramlara Anderson (1983) ve Hobbs'un (2016) çalışmasında yer bulan; şiddet, materyalizm, beslenme, beden imgesi, risk alma davranışı, içerikte saptırma, önyargı, ırk, sınıf ve cinsiyet ayrımı, aşırı duyarlılık, şiddet, mesaj güvenilirliği, siber zorbalık, pornografi ve çevrimiçi sosyal sorumluluk gibi kavramları da eklemek mümkündür.

Medya okuryazarlığı anlayışına göre medya içeriklerine yönelik; bilinç oluşturma ve değerlendirme yapma için başvurulan iki anlayış vardır. Bunlardan biri korumacı medya okuryazarlığı anlayışı ve bir diğeri de eleştirel medya okuryazarlığı anlayışıdır. Korumacı medya okuryazarlığı anlayışı, medya içeriklerindeki; kültürel, ahlâki ve ideolojik hususlara savunmacı bir anlayışla bakar (Buckingham, 2006, s.70). Ertürk ve Akkor'un (2006, s.48) çalışmasında bu durum “medyadan uzak durmayı veya kaçınmayı önemseyen bir anlayış" olarak açıklanır. Bu ve benzer nedenlerle korumacı medya okuryazarlığı anlayışı; etkin ve uygun bir medya okuryazarlık anlayışı değildir. Eleştirel medya okuryazarlık anlayışı ise medyadan kaçmadan, medya içeriklerinde var olan olumlu ve olumsuz içerikleri tespit etmeyi ve bunlara yönelik eleştirel temelde değerlendirme yapmayı esas alır. Bir anlamda medya içeriklerini; "seçerek alma becerisi kazanma yaklaşımı olarak ta açıklanabilir" (UNESCO, 2006). Bu yönleriyle eleştirel medya okuryazarlık anlayışı etkin ve uygun bir medya okuryazarlık anlayışıdır.

Medya okuryazarlık anlayışını kazandırmak için okullarda da bir kısım etkinlikler yapılır. Bunlardan biri medya okuryazarlığının öğretim programına bağlı bir ders olarak okutulmasıdır. Türkiye'de, medya okuryazarlığı dersi okullarda seçmeli ders olarak okutulur. Bu dersin öğretim programı, dersin yedi genel amacı olduğunu ele alır. Bunlardan biri: "yazılı, görsel ve işitsel medyaya yönelik eleştirel bakış açısı kazanmaktır" (Milli Eğitim Bakanlığı, 2009). Bu amaç, Türkiye'deki okullarda okutulan seçmeli medya okuryazarlık dersi öğretim programının; eleştirel medya okuryazarlık anlayışı ile planlandığını söyleme fırsatı da verir.

Alandaki çalışmalarda, bu dersin öğretiminde birçok sorun ve eksikliğin var olduğunu ele alır. Bunlar şöyle derlemek mümkündür: Öğrenciler, derste kullanılan araç ve gereçleri ve dersle ilgili sınıf içi tartışmaları yeterli bulurken, sınıf içi etkinlikleri ve kullanılan öğretim yöntemlerini yeterli bulmamakta ve öğretmenin dersi işleyiş biçimini beğenmemektedir (Elma, Kesten, Dicle, Mercan, Çınkır ve Palavan 2009, s.93). Medya Okuryazarlığı dersi öğretmen kılavuz kitabını değerlendiren Ülker'in, (2012) çalışmasında ise bu kitabın karışık olduğu ve öğretim programındaki kazanım beklentileriyle, bazı etkinliklerin örtüşmediği gibi sorun alanlarının varlığı görülmüştür. Şahin (2015) yaptığı bir çalışmada; öğretmenlerin öğretim materyali olarak en çok ders kitabı, yazılı doküman ve yazı tahtasını kullandıkları sonucuna ulaşmıştır. Ders içi etkinliklerde en çok kullanılan kitabın, medya okuryazarlı̆̆ı öğretmen kılavuz kitabı örneğinde eksiklilerini Şeylan'ın (2008, s.32-53) çalışmasında; politik ve toplumsal konular üzerinde düşünmeye zemin hazırlamaktan uzak olduğu ve derslerin, gündelik yaşam veya başka bir deyişle uygulanabilir metinle çözümlenmediği gibi eksikler barındırdığı da saptanmıştır. Radyo ve Televizyon Üst Kurulu’nun, medya okuryazarlığı konusunda geçmişten beri birçok çalışma yaptığı, bunları yayınladığı ve bunların alana önemli katkılar sağladığı değerlendirilmektedir. Bu bağlamda yapılan çalışmalardan biri Radyo ve Televizyon Üst Kurulu (RTÜK; 2016, s. 234-235)'de ele alınmıştır. Bu çalışmada, medya okuryazarlığıyla ilgili görüşlere katkı sunacak önemli sonuçlara yer verildiği görülmüştür. Bunlardan biri olan medya okuryazarlı̆̆ıla ilgili ders içi uygulamalara yönelik öğrenci görüşleridir. Bu görüşlerde elde edilen bulgulara göre; ders içi uygulamalarda öğrencilerin sadece $\% 42$ 'si derste kullanılan araç-gereçleri ve $\% 52$ 'si ders kitabının yeterli olduğunu düşünmektedir. Ayrıca öğrencilerin \%43'ü ders içi etkinlikleri ve \%62'si dersin işleniş biçimini yeterli bulmaktadır. Öğrencilerin \%44'ü dersin içeriği, işleyiş biçimi ve kitabın içeriğinin ise daha çok geliştirilmesi gerekliliğine vurgu yapmıştır. Özellikle ders içi uygulamaların artırılması, derste çeşitli medya araçlarının daha etkin kullanılması durumunda öğrenciler açısından dersin daha zevkli bir hal alacağı da belirtilmiştir. Buna benzer başka bir çalışma ise Türkiye'de medya okuryazarlığı eğitimi alanındaki çalışmaları; tematik, metodolojik ve istatistiksel yönelimlerle analiz eden Aydemir ve Erdamar'ın (2018, s.1163) çalışmasıdır. Bu çalışmaya göre; ders etkinliklerinin

| Kastamonu Eğitim Dergisi, 2020, Vol. 28, No. 3| 
uygulamalarla zenginleştirilmesi (\%13.5), medya okuryazarlığı eğitimini destekleyici materyallerin hazırlanması/geliştirilmesi (\%12.5) ve medya okuryazarlığı programının geliştirilmesi (\%9.6) oranla alandaki çalışmalara konu olmuştur.

Tüm bu sorun alanlarının yanında medya okuryazarlığı öğretim programı ile öğretim araç ve gereçleri; hem içerik hem de konu temelinde TV'ye yoğunlaşmaktadır. Diğer medya mecraları bu süreçte göz ardı edilmekte ve TV ile kıyaslandığında, diğer medya mecralı neredeyse yok denilecek seviyede yer bulmaktadır.

Yukarıdaki verilere bir bütün olarak bakıldığında, medya okuryazarlığı öğretim süreci, araç ve gereci, ders içi etkinlikleri, dersin işleyiş biçimi ve ders içi uygulamaları başta olmak üzere sistemin tüm unsurlarında önemli eksiklik ve sorunlar vardır. Medya okuryazarlığı sürecinde yaşanan bu sorun ve eksikliklerin giderilmesine katkı sağlamanın yanında alandaki uygulamaları çeşitlendirip, zenginleştirecek, farklı medya mecralarını önceliğe alacak özgün bir çalışmanın yapılması yerinde, gerekli ve önemli görülmüştür.

Bu çalışmanın; kapsam, maliyet ve zaman gibi sınırlılıkları vardır. Çalışmanın kapsam sınırlılığı bağlamında medya okuryazarlığı sürecinde yaygın kullanılan TV dışında bir medya mecrasını konu etmesinin daha etkin, uygun ve özgün olacağı düşüncesi vardır. Bu nedenle çalışma, TV'den sonra en etkin medya mecrası olan gazeteyi konu etmiştir. Veri kaynaklarına ulaşma kolaylığı açısından, araştırmacı; çalışma döneminde Güney Afrika Cumhuriyeti (Güney Afrika)'nde bulunduğu için çalışma nesneleri olarak Güney Afrika'daki gazeteler seçilmiştir. Ayrıca çalışmayı yapanın eğitim alanındaki uzmanlığı da dikkate alınarak, gazete içeriklerinde eğitimle ilişkili konular üzerine çalışılmıştır. Maliyet ve zaman sınırlılıklar bakımından ise bu çalışmanın veri toplama bölümünde açıklandığı gibi belli dönemdeki gazetelerde, eğitimle ilişkili içerikler çözümlenmiştir. Bu sınırlılılar da dikkate alınarak bu çalışmanın amacı şöyledir: Gazete içeriklerinin, eleştirel medya okuryazarlığı anlayışıyla değerlendirip, olumlu veya olumsuz medya içeriklerini betimlemektir. Bu amaca ulaşmak için şu sorulara cevap aranmıştır:

1. Çalışma konusu gazeteler, içerik analiziyle çözümlendiğinde elde edilen bulgular nelerdir?

2. Çalışma konusu gazeteler, medya okuryazarlığı içerik -tema- ve biçim formu verileriyle analiz edildiğinde elde edilen bulgular nelerdir?

\section{YÖNTEM}

Bu çalışma, nitel araştırma yöntemiyle yapılmıştır. Veriler doküman analizi yöntemiyle toplanmıştır. İçerik analizi yöntemiyle ve araştırmacı tarafından geliştirilen medya okuryazarlığı içerik -tema- ve biçim formu ile çözümlenmiştir. Buralarda elde edilen veriler, ihtiyaç duyulduğunda, alandaki çalışmalarla da desteklenerek betimlenmiştir. Bu betimlemelerle; gazetelerdeki medya mesajlarının, eleştirel medya okuryazarlığı anlayışına göre olumlu veya olumsuz olma durumu; tartışma, sonuç ve önerilerle ortaya konmuştur.

\section{Çalışma Nesnesi ve Konusu}

Bu çalışmanın, doküman analizi sürecinde kullanılan çalışma nesneleri, medya ve medya okuryazarlığı alanındaki çalışmalara konu olmuş hususlardır. Çalışma konusu ise eleştirel medya okuryazarlığı anlayışına uygun okul düzeyinde ve öğretimle ilişkili alan çalışmalarıdır. Veri çözümleme sürecinde kullanılan çalışma nesnesi ise Güney Afrika'da İngilizce dilinde, ulusal düzeyde, Ocak 2016 ile Mart 2016 tarihleri arasında yayınlanmış gazetelerdir. Çalışma nesneleri, basılı biçimiyle satın alınan, her hafta ortalama 10 ve toplamda 120 gazeteden oluşmuştur. Veri çözümleme sürecinde kullanılan çalışma konuları ise The Star, The Times, The Citizen, The Pretoria News, City Press, The NewAge ve Newspaper gazetelerine Güney Afrika eğitim sistemiyle ilgili içeriği olan 18 gazetedir.

\section{Veri Toplama Araç ve Teknikleriyle Verilerin Analizi}

Çalışmaya, medya okuryazarlığı konusuyla ilgili bilgilerin bulunması, araştırmaya kuramsal bir temel kazandırılması ve benzer çalışmaların sonuçlarının görülmesi için basılı ve dijital belgelerin taranıp gözden geçirilmesi ve değerlendirilmesi ile yani veri toplanması ile başlanmıştır. Doküman analizi ile elde edilen bulgular ve onlara bağlı çalışma konuları içerik analizi yöntemiyle çözümlenmiştir. İçerik analizi yöntemiyle çözümleme yapma nedeni Yıldırım ve Şimşek'in (2018) çalışmasında açıklandığı gibi dokümanlar (çalışma nesnesi ve alandaki çalışmalar), tüm veri setini oluşturduğu için, detaylı bir içerik analizi yöntemi kullanılarak yapılmıştır. İçerik çözümlemesi için “belli özellikler, objektif ve sistematik bir şekilde tanımlanmıştır” (Büyüköztürk, Çakmak, Akgün, Karadeniz \& Demirel, 2008, s.245-248). Bu içerikler: "homojen, ayırt edici ve objektif biçimde, anlamlı ve bütünsel kategorilere ayrılmıştır" (Bilgin, 2006, s.19). Bunun sonucunda dört kategori elde edilmiştir. Bu çözümlemeye ek olarak eleştirel medya okuryazarlığı anlayışına uygun biçimde içerik çözümlemesi için araştırmacının geliştirdiği medya okuryazarlığı içerik -tema- ve biçim formu da kullanılmıştır. Bu form bulgular bölümünde yer alan; tablo-4, tablo-5, tablo-6 ve tablo-7'de yer almaktadır. Çalışmada bu formun geliştirilmesi ve kullanılmasının nedeni, çalışma kapsamıyla uyumlu daha önce geliştirilmiş bir veri toplama aracının alandaki çalışmalarda yer almamasından kaynaklanmıştır. Bu formun, eleştirel medya okuryazarlık çalışmalarının, öğretim programına bağlı öğretim sürecinde medya mecralarından gazete içeriklerindeki olumlu ve olumsuz sunumları tespit etmek, üzerine değerlendirme yapılmak ve bu yolla medya içeriklerine yönelik bilinç oluşturma gayretine, betimleme yaparak katkı sunmayı amaç edinmiştir.

Araştırmacının geliştirdiği bu formu üç temel bölümünden oluşmuştur. Bunların ilki içerik -tema- bölümüdür. İkincisi biçim bölümü ve üçüncüsü ise değerlendirme bölümdür. Formun, içerik -tema- bölümünde medya içeriklerindeki; metin, içerik ve dilin çözümlemesini amaç edinmiştir. Metin çözümlemesi; içeriğin geçtiği yer, tema olarak seçilen konu, konunun ele alış biçimi, vurgu 
yapılan çarpıcı noktalar, kullanılan dil, seçilen oyuncu ile vurguların gerçek amacı ve muhtemel olumsuz etkileri okuyucunun bakış açısı gibi hususlar etrafında açıklamaya fırsat verecek içerikte yer bulmuştur. İçerik çözümlemesi ile içeriğin okuyucuda ne çağrıştırdığı ve içerikler arasındaki ilişkileri ortaya koymak için yapılmıştır. Bu süreçte içeriğe yönelik algılama farklılığı ve buna bağı farklı görüşlerin tartışılması, kattığı farklı ve yeni anlamlar ile bakış açısına bağlı çözümleme de yapılması da amaçlanmıştır. Dilin çözümlenmesi sürecinde ise medya mecrasının izleyiciye ulaşırken kullandığı dil ve izleyici ile kurulan ilişkiyi değerlendirme yoluyla kurulan çözümleme biçimi olarak yer almıştır.

Araştırmacının geliştirdiği formun biçim bölümünde ise medya içeriğindeki olumlu veya olumsuzlukları, medya içeriğinin sunum biçimi ile çözümlenmesini amaç edinmiştir. Formun bu bölümü, öncelikle içeriği hazırlayanların, içeriğe verdikleri önem derecesinin tespitine yönelmiştir. Bu amaçla içeriğin, konumu ve tasarım biçimle ilişkili verilere başvurulmuştur. İçeriğin yeri; kapak, iç, son ve ek sayfa ya da sayfalarda olabilir. Bazı içerikler tematik konu başlıklarının yer aldığı sayfalarda bulunabilir. Bu sayfalar; ekonomi, eğlence, eğitim, spor, bulmaca gibi başııkla sunulabilir. Ek sayfalar ise belirli bir temaya yönelik özel içeriklerin yer aldığı dönemsel, tek veya birden çok seferde yayınlanan bölümlerde yer alabilir. İçeriğin konumu ise üst-alt, orta ve sol-sağ gibi konumlar ile bunların kesişme noktalarında yer alabilir. Tasarım biçimi ise manşet, anonslu, köşe yazısı, küçük-büyük yazı fontlu, çerçeveli, dolgulu, renkli, metin yanında resim, grafik (şekil ve tablo) ve elektronik formlu gazeteler için video ve benzer tasarım biçimleriyle sunulabilir.

Araştırmacının geliştirdiği medya okuryazarlığı içerik -tema- ve biçim formunun üçüncü bölümü olan değerlendirme bölümde ise birinci bölümdeki içerik -tema- ve ikincisi bölümdeki biçim bölümünde elde edilen verilerin bir bütün olarak çözümlenmesini amaç edinmektedir.

Araştırmacının geliştirdiği bu formun kabul edilebilirlik ve kapsam geçerliliği için iki ayrı süreçte dört kişinin görüşüne başvurulmuştur. Görüşlerine başvurulan kişilerin ikisi gazetecilik bölümü mezunu ikisi de ilköğretim okulu öğretmenidir. Bunlardan önce araştırmacı tarafında geliştirilen formu; medya ve medya okuryazarlığı ekseninde, gazete medya mecrası özelinde okumaları, varsa anlaşılmayan, açık olmayan hususları, eksik, fazlalık ve yanlışlıklara yönelik görüşlerini bildirmeleri istenmiştir. Bu süreçte form üzerinde küçük anlatım ve imla hataları yapıldığı tespit edilmiş ve bunlar düzeltilmiştir. Ayrıca medyanın olumlu tarafı, gazete medya o mecrası üzerinde müzakere yapılmıştır. Buna göre medyanın olumlu tarafını temsil eden bilgilendirme-eğitme kavramı, tek parça yerine ayrı ayrı yer alması ve sosyalleşme kavramının da eklenmesi yönünde fikir birliği oluşmuştur. Bu fikir birliği bahse konu forma işlenmiştir. İkinci süreçte ise bu dört kişiden, araştırmacının daha önce veri kaydını yaptığı beş ayrı çalışma konusunu, araştırmacının kaydını bilmeden ve araştırmacı tarafından kullanılan bu formu kullanarak çözümlenmesi istenmiştir. Araştırmacının veri kaydı ile görüşlerine başvurulan dört kişinin veri kaydı arasında anlamlı bir farkın olmadığı görülmüştür. Bundan sonra tüm çalışma konularına yönelik veriler, araştırmacı tarafından bu forma kullanılarak kayıt edilmiş ve çözümlenmiştir. Tüm bu süreçlerin sonunda, çalışma konularındaki olumsuz medya içerikleri, içerik çözümlemesi, bu formdaki veriler ve doküman analiziyle elde edilen yeni verilerle desteklenerek tartışılmıştır. Bu yolla elde edilen verilerle sonuç ve önerilere yer verilerek çalışma tamamlanmıştır.

\section{BULGULAR}

Çalışmanın amacına uygun sorulara cevap bulmak için yapılan analizlerle aşağıdaki bulgular elde edilmiştir.

\section{Çalışma konusu gazeteler, içerik analiziyle çözümlendiğinde elde edilen bulgular nelerdir?}

Çalışma konusu gazeteler, içerik analiziyle çözümlendiğinde; homojen, ayırt edici ve objektif biçimde, anlamlı ve bütünsel dört kategori elde edilmiş ve bunlar tablo-1'de verilmiştir.

Tablo 1. Çalışma konularının kategorilere göre dağılımı tablosu.

\begin{tabular}{|c|c|c|c|c|}
\hline Kategori adı & Sira No & Konusu & $\begin{array}{c}\text { Gazetenin adı, sayfa ve } \\
\text { sutunu }\end{array}$ & Varsa yazarı veya kaynağı \\
\hline \multirow{5}{*}{$\begin{array}{l}\text { Üniversite } \\
\text { öğrenci } \\
\text { eylemleri }\end{array}$} & 1 & \#AfrikaansMustFall & The Times, ss. 4-8. & Goba, (2016, Mart 21) \\
\hline & 2 & \#OutsourcingMustFall & Star Letter, ss 7-4. & (2016, Şubat 19) \\
\hline & 3 & \#feeMustFall & Pretoria News, ss. 1-6. & Makhetha, (2016, Şubat 17) \\
\hline & 4 & \#RhodesMustFall" & The Star, ss. 1-9. & (2016, Mart 10) \\
\hline & 5 & \#ZumaMustFall & The Star, ss. 8-8. & Petersen, (2016, Mart 10) \\
\hline \multirow{4}{*}{ Metrik sınavları } & 6 & $\begin{array}{c}\text { Metrik sınavı sonucunda öğrenci başarısındaki } \\
\text { düşüklük, alınması gereken tedbirler, alternatif } \\
\text { öğrenim fırsatları ve yükseköğretimin dışında } \\
\text { kalanlar için hayata atılma yolları. }\end{array}$ & The Newage, ss 5-4 & Madisha, (2016, Şubat 16) \\
\hline & 7 & $\begin{array}{l}\text { Metrik sınavı sonucuna yönelik okul ve aile } \\
\text { katılımıyla yapılan değerlendirme toplantısı. }\end{array}$ & $\begin{array}{l}\text { The Newage: Analist, ss. } \\
\qquad 14-3\end{array}$ & Ek \\
\hline & 8 & $\begin{array}{l}\text { Yükseköğretim dışında kalanlara mali katkı vererek } \\
\text { hayata atılmalarının teşvik edilmesi. }\end{array}$ & $\begin{array}{l}\text { The Independent. ss. } \\
\text { Att-5. }\end{array}$ & $\begin{array}{l}\text { Nzimande, B. (2016, Şubat } \\
\text { 23). }\end{array}$ \\
\hline & 9 & Metrik sınavlarındaki şok düşüş! & Daily News, ss. 7-4. & Mlambo, S. (2016, Şubat 4) \\
\hline \multirow{2}{*}{$\begin{array}{l}\text { Bilişim } \\
\text { teknolojisi } \\
\text { temelli çalışma }\end{array}$} & 10 & Kâğıtsız sınıflar projesi & Daily News, ss. 7-4. & $\begin{array}{c}\text { Monama, T. (2016, Şubat } \\
\text { 12) }\end{array}$ \\
\hline & 11 & Akıllı okullar projesi & The Citizen, ss. 8-3. & Phaladi, B. (2016, Şubat 10) \\
\hline
\end{tabular}

| Kastamonu Eğitim Dergisi, 2020, Vol. 28, No. 31 


\begin{tabular}{|c|c|c|c|c|}
\hline Kategori adı & Sira No & Konusu & $\begin{array}{l}\text { Gazetenin adı, sayfa ve } \\
\text { sutunu }\end{array}$ & Varsa yazarı veya kaynağı \\
\hline \multirow{7}{*}{ Diğerleri } & 12 & Kâğıtsız sınıf ve akıllı okul projeleri & City Press, ss. 10-6. & Prince, L. (2016, Şubat 28) \\
\hline & 13 & Öğrencisi kalabalık olan sınıflar. & The Star, ss. 11-4. & $\begin{array}{c}\text { Monama, T. (2016, Şubat } \\
\text { 12) }\end{array}$ \\
\hline & 14 & $\begin{array}{c}\text { Öğretmenlerin izin veya sağlık raporu kullanmaları } \\
\text { ve ortaya çıkan aksaklıklar. }\end{array}$ & Daily News, ss. 7-4. & Mlambo, S. (2016, Şubat 4) \\
\hline & 15 & $\begin{array}{c}\text { Ekonomik yetersizliğe dayalı gerekçelerle eğitime } \\
\text { erişim engelleri. }\end{array}$ & The Newage, ss. 7-6. & Antuli, N. (2016, Ocak 15). \\
\hline & 16 & $\begin{array}{l}\text { Ekonomik yetersizliğe dayalı gerekçelerle eğitime } \\
\text { erişemeyenlere, ekonomik katkı sağlayarak } \\
\text { eğitime dâhil olmaları konulu kampanyalar. }\end{array}$ & The Star, ss 8-2 & $\begin{array}{l}\text { Mitchley. A. (2016, Şubat } \\
\text { 10) }\end{array}$ \\
\hline & 17 & $\begin{array}{l}\text { Güney Afrika eğitim sistemindeki başarısızlık } \\
\text { nedenlerinden }\end{array}$ & The Star, ss. 8-8. & Petersen, C. (2016, Mart 10) \\
\hline & 18 & $\begin{array}{l}\text { Analiz: Bantu eğitim sistemi, fiziksel ortam, } \\
\text { öğretim programı, araç-gereç, okul-aile-çevre } \\
\text { ilişkisi, mali kaynak temini, işbirliği geliştirme ve } \\
\text { öğretimin felsefi temeline yönelik analizler. }\end{array}$ & $\begin{array}{l}\text { The Newage: Analist, ss. } \\
\qquad 14-3\end{array}$ & Morero, D. (2016, Şubat 16) \\
\hline
\end{tabular}

Üniversite öğrenci eylemleri başlıklı kategoride yer alan çalışma konusu içerik özetleri tablo-2'de verilmiştir.

Tablo-2. Üniversite öğrenci eylemleri başlıklı kategorideki çalışma konusu içerikleri.

\begin{tabular}{|c|c|c|}
\hline Kategorisi & $\begin{array}{c}\text { Sira } \\
\text { no }\end{array}$ & Çalışma konusunun içeriği \\
\hline \multirow{4}{*}{$\begin{array}{l}\text { Üniversite } \\
\text { öğrenci } \\
\text { eylemleri }\end{array}$} & 1 & Afrikansca, zorunlu öğrenim dili olmamalı anlamına gelen “\#AfrikaansMustFall” teması içerik olmuştur. \\
\hline & 2 & $\begin{array}{l}\text { Sözleşmeli çalışanlar, kadroya alınmalı anlamına gelen “\#OutsourcingMustFall” temalı içerik haber yapılmıştır. Bu } \\
\text { içerikte Economic Freedom Fighters (Ekonomik Özgürlük Mücadelecileri (EFF)) partisinin, öğrenci komutanına } \\
\text { dayanan açıklamaları da yer bulmuştur. Ayrıca dört gündür süren eylemlere, } 2000 \text { civarında EFF'li öğrencinin katıldığı } \\
\text { da belirtilmektedir. Yüksek Öğretim Bakanlığından bir temsilcinin görüşüne de yer verilmiştir. Onun görüşüne göre } \\
\text { üniversitelerde, protesto yolu ile okul ve derslikleri kapatma eylemleri doğru değildir. Ayrıca 2007'de güncellenerek } \\
\text { yeniden düzenlen Güney Afrika'daki Yüksek Öğretim kanunu; kalkınma planlarında ve 1997'de kabul edilen Eğitim } \\
\text { Bakanlığının, Beyaz Rapor, 3, esas alınarak, hükümetin öncelikleri ve programları ile uyumu icra edilmektedir. } \\
\text { Devamında yükseköğretimin temel prensiplerini de açıklamıştır. Ona göre yükseköğretimin temel prensipleri } \\
\text { arasında gençlerin, kaliteli ve eşitlikçi eğitim almasına fırsat sunmak, akademik özgürlük, enstitülerin bağımsızlığı, } \\
\text { hesap verilebilirlik ve ön diyalog gibi hususlar vardır. }\end{array}$ \\
\hline & 3 & $\begin{array}{l}\text { Öğrenim ücreti kaldııımalı anlamına gelen \#feeMustFall temalı içerik haber yapılmıştır. Burada öğrenci eylemlerine } \\
\text { yönelik kamu yetkililerinin karşı açıklamalarına da yer vermiştir. Kamu yetkilileri: Taleplerin değerlendirileceğini ele } \\
\text { almıştır. Devamında bu tür taleplere yönelik öğrenci hareketlerine dayalı hak arama yolunun doğru olmadığı, bu } \\
\text { konudaki kararların, üniversite senatolarında alınması gerektiği de vurgulanmıştır. Bu içeriklerin yanında, farkı iki } \\
\text { gazetede bu kategoriyle ilişkili içeriklerde yer bulmuştur. }\end{array}$ \\
\hline & 4 & Rhodes felsefesi yok olmalı anlamına gelen, \#RhodesMustFall temalı içerik haber yapılmıştır. \\
\hline
\end{tabular}

Üniversite öğrenci eylemleri başıklı kategoride, tablo 2'de görüldüğü gibi beş ayrı çalışma konusu vardır. Çalışma konularındaki içerikler; \# sembolü ile başlamış ve hemen devamında bir tema ve MustFall ifadesi kullanılmışır. Bu temalı içeriklerin, eğitim sistemiyle ilişkili olanları Güney Afrika'daki öğrencilerin ülkedeki 11 resmi dilden biri olan ve Hollanda kökenlilerin ana dili olan Afrikansca dilinin, öğretim programında zorunlu olarak yer almamasını isteyen \#AfrikaansMustFall ve öğrenim ücretlerinin kaldırılmasını isteyen \#feeMustFall teması ile kullanıldığı görülmüştür. Bunlar dışında eğitim sistemiyle doğrudan ilişkili olmasa da benzer formatta bazıları öğrenci eylemleriyle birlikte sunulmuş, siyasi ve ideolojik içerikli; \#OutsourcingMustFall, \#RhodesMustFall ve \#ZumaMustFall temalı içeriklerde kullanılmıştır.

\#OutsourcingMustFall teması, sözleşmeli çalışanlar kadroya alınmalı anlamına gelmektedir. \#RhodesMustFall, Rhodes anlayışı yok olmalı anlamına gelmekte ve \#ZumaMustFall teması, 2009'dan beri devlet başkanlığı yapan ANC partisi genel başkanı Jacob Zuma'nın görevden ayrılmasını isteyen bir temadır. Jacob Zuma bu verilerin toplanmasından daha sonraki bir denemde -2018'deistifa ederk görevinden ayrılmıştır. Bu kategorideki içeriklerin dört tanesi; The Star ve bir tanesi; Pretoria News gazetesinde yer bulmuştur.

Metrik sınavları başlıklı kategoride yer alan çalışma konusu içerik özetleri tablo-3'de verilmiştir. 
Tablo 3. Metrik sınavı sonuçları başlıklı kategorideki çalışma konusu içerikleri.

\begin{tabular}{|c|c|c|}
\hline Kategorisi & $\begin{array}{c}\text { Sira } \\
\text { no }\end{array}$ & Çalışma konusunun içeriği \\
\hline \multirow{4}{*}{$\begin{array}{l}\text { Metrik } \\
\text { sınavları }\end{array}$} & 6 & $\begin{array}{l}\text { Metrik sınavı sonucunda Kuwazulu-Natal Bölgesi (KNZ)'ndeki } 12 \text { okulun hiç başarı göstermediğine yer verilmiştir. } \\
\text { Aynı gazetenin başka bir sayısında ise KZN'indeki } 12 \text {. Sınıların metrik sınav sonuçları, bir önceki yıla göre } 9 \% \\
\text { oranında düşmüştür. Bu düşünüşün değişik boyutlarıyla değerlendirileceği bir toplantının yapılacağı yer almaktadır. } \\
\text { Toplantıya eyalet ve bölge siyasetçileri ile belediye ve okul temsilcilerinin yanında ailelerin de katılacağı ele } \\
\text { alınmıştır. }\end{array}$ \\
\hline & 7 & $\begin{array}{l}\text { Ulusal Mali Yardım Politikaları (UMYP)'in, } 21 \text { ana sektörde üniversite ve mesleki eğitim ve iş kurmaya yönelik mali } \\
\text { destek sağlayan bir program tanıtılmıştır. Ayrıca metrik sınavında başarısız olan ve üniversiteye gidemeyecek } \\
\text { öğrencilerin UMYP katkı mekanizmalarından faydalanabilecekleri ele alınmıştır. }\end{array}$ \\
\hline & 8 & $\begin{array}{l}\text { Metrik sınavındaki, başarı oranının düşmesi konu olmuştur. Burada; kaliteli ve eşitlikçi eğitimin yapılamadığından } \\
\text { bahsetmektedir. }\end{array}$ \\
\hline & 9 & $\begin{array}{l}\text { Metrik sınavındaki düşük başarı düzeyi konu edilmiştir. Bakanlık yetkililerinin görüşlerine de yer vermiştir: Metrik } \\
\text { sınavındaki başarı oranındaki düşüklüğün nedenlerinden biri olarak ölçme ve değerlendirme sonucunun Güney } \\
\text { Afrika'daki toplulukları temel alınarak açıklanması olarak değerlendirir ve sonuçların geçmiş yıllarla kıyaslanmasını } \\
\text { doğru bulmaz. Buna rağmen sonuçların; derinlemesine analiz edileceği ve varsa sorun alanlarının tespit edilip } \\
\text { çözüme kavuşturulacağı ele alınmışır. Bunun yanında ülke kaynaklarının etkin kullanılması da dikkate alınarak, } \\
\text { alternatif olarak başarısız öğrencilerin mesleki eğitime yönlendirileceğini de açıklamıştır. }\end{array}$ \\
\hline
\end{tabular}

Metrik sınavı sonuçları başlıklı kategoride, tablo 3'te de görüldüğü gibi üç ayrı çalışma konusu vardır. Bunlar; 6, 7 ve 8 kodludur. Bu içerikler metrik sınavıyla ilişkilidir. Metrik sınavı, Güney Afrika'da çıktı temelli öğretim programı tasarımı ile diploma ve üniversiteye yerleştirmeye de esas, açık uçlu soru teknikli, ölçme ve değerlendirmeler içeren, lise son sınıf ile mezunlarının katıldığı bir sınav sistemidir. Çalışma konuları, bu sınavlar sonucuna göre öğrenci başarısındaki düşüklük, buna yönelik alınacak tedbirler, alternatif öğrenim fırsatları veya yükseköğretimin dışında kalanlar için hayata atılma yolları konu etmiştir. İçeriklerde; kamu tarafı yetkililerin eleştiri veya suçlamalara yönelik karşı görüşleri ve başarısız öğrenciler için hayata atılma önerileri ve sağlanması muhtemel mali katkılarda konu olmuştur.

Bilişim teknolojisi temelli çalışmalar başlıklı kategoride yer alan çalışma konusu içerik özetleri tablo-4'de verilmiştir.

Tablo-4. Bilişim teknolojisi temelli çalışmalar başlıklı kategorideki çalışma konusu içerikleri.

\begin{tabular}{|c|c|c|}
\hline Kategorisi & Sira no & Çalışma konusunun içeriği \\
\hline \multirow[b]{3}{*}{$\begin{array}{l}\text { Bilişim } \\
\text { teknolojisi } \\
\text { temelli } \\
\text { çalışmalar }\end{array}$} & 10 & $\begin{array}{l}\text { Akıllı okullar projesi hakkında haber yer almaktadır. Bu haberde proje hakkında Eğitim Bakanlığından bir } \\
\text { sözcünün açıklamaları yer bulmaktadır. Buna göre: } 2015 \text { yılında dağıtılan } 64000 \text { tabletin, \% } 81 \text { 'inin geri geldiği } \\
\text { buna karşın } 12000 \text { tabletten birçoğunun polis raporlarında da yer aldığı şekli ile çalındığı konu edilmektedir. } \\
\text { Haberin devamında; tedbir olarak, tabletlere dağıtılmadan önce bu tür muhtemel sorunlara karşı takip } \\
\text { yongasının takılığı ancak bu yongaların, kaybolan tabletlerin önemli bir kısmında sökülüp atıldığı çcin takibin de } \\
\text { imkânsızlaştığına yer verilmektedir. }\end{array}$ \\
\hline & 11 & $\begin{array}{l}\text { Bu gazetedeki haber de akıllı okullar projesi hakkındadır. Haberde; öğrencilere verilen tabletlerin kayıp } \\
\text { olduğunu, bazılarının yongaları sökülüp atıldığı için bulunamadığı da ele alınmıstır. }\end{array}$ \\
\hline & 12 & $\begin{array}{l}\text { Kâğıtsız okul ve akıllı okullar projesi konu edilmektedir. Kâğıtsız okul projesi, proje yöneticisinin açıklamaları } \\
\text { haber yapılmıştır. Haberlerde, kâğıtsız okul projesinin, } 2015 \text { 'de pilot uygulama şeklinde; } 7 \text { okulda } 12 \text {. sınıfta } \\
\text { başlatıldığı bildirilmektedir. Önümüzdeki yıllarda önce eyaletteki tüm okulların } 12 \text {. sınıflarını, daha sonra sıra ile } \\
\text { 11. ve } 10 \text {. sınıflarını ve } 5 \text { yıl sonunda da 8-9'ncu sınıfların projeye dahil edileceği bildirilmektedir. Ayrıca proje } \\
\text { bütçesinin } 17 \text { Milyar Rand (yaklaşık } 1.2 \text { milyar \$) olduğu, proje ile öğrenci başarısı ve öğrenme performansının } \\
\text { arttııımasının beklendiği, } 62000 \text { öğrenciye ulaşarak } 2018 \text { 'de tamamlanacağı vurgulanmıştır. Akıllı okullar projesi } \\
\text { ise Guateng eyaleti eğitim biriminde yetkililerin açıklamalarıyla yer bulmaktadır. Buna göre Guateng eyaletinde, } \\
\text { öğrencilerin öğretim araç ve gereçlerine okul içinde ve dışında ulaşma fırsatı verdiği bildirilmektedir. Bu projede } \\
\text { haberin yapıldığı zamana kadar okullarda } 88000 \text { tablet bilgisayarın kullanılmaya başlandığı ele alınmışırır. Proje } \\
\text { ile okullara internet bağlantısı, öğretmenlere; lap-top bilgisayar ile öğrencilere tablet bilgisayar temin } \\
\text { edilmesinin planlandığı vurgulanmaktadır. Ayrıca öğretim ortamlarında ise; akıllı tahta, e-kitap ve çoklu ortam } \\
\text { içeriklerine daha çok yer verileceği bildirilmiştir. }\end{array}$ \\
\hline
\end{tabular}

Bilişim teknolojisi temelli çalışmalar başlıklı kategoride, tablo-4'de görüldüğü gibi üç ayrı çalışma konusu vardır. Bunlar; 10, 11 ve 12 kodludur. Bu içeriklere özetle; kâğıtsız sınıflar projesi ve akıllı okullar projesi konu olmuştur.

Diğer konular başlıklı kategoride yer alan çalışma konusu içerik özetleri tablo-5'de verilmiştir. 
Tablo-5 Diğer konular başlıklı kategorideki çalışma konusu içerikleri.

\begin{tabular}{|c|c|c|}
\hline Kategorisi & Sira no & Çalışma konusunun içeriği \\
\hline \multirow{6}{*}{ Diğer konular } & 13 & $\begin{array}{l}\text { Haberde, Temel Eğitim Bakanı Ange Motshekga'nın, kalabalık öğrencili sınıflara yönelik yaptığı durum } \\
\text { değerlendirmesi konu edinmiştir. Bakan: kalabalık öğrencili sınıfların; fakir, geri kalmıs ve şehir merkezlerinde } \\
\text { karşılaşılan bir sorun olduğunu bildirmektedir. Sorunun çözümü için önerileri de ele almıştır. Ona göre kalabalık } \\
\text { okullardaki öğrencilerin, diğer okullardaki her sınıfa } 5 \text { öğrenci yerleştirilmek veya mobil sınıflar kurmak gibi } \\
\text { alternatif çözüm yollar üzerine çalıştıklarını açıklamıştır. }\end{array}$ \\
\hline & 14 & $\begin{array}{l}\text { Öğretmenlerin izin veya sağlık raporu aldıkları, bunun sonucu eğitim-öğretim ortamından uzun süreyle } \\
\text { uzaklaştıkları bu haberde konu edilmektedir. Bunun ise eğitim-öğretim işini aksattığı ele alınmıştır. Öğretmenler, } \\
\text { bu durumun ihmal veya görevden kaçma sebebiyle değil, sağıı sorunlarının neden olduğunu söyledikleri de ele } \\
\text { alınmıştır. }\end{array}$ \\
\hline & 15 & $\begin{array}{l}\text { Haberde, ekonomiye dayalı yetersizlikleri olan başarılı öğrencilerin eğitime devamlarını sağlamak ve onlara mali } \\
\text { kaynak sağlamak için düzenlenen kampanyalar konu olmuştur. }\end{array}$ \\
\hline & 16 & $\begin{array}{l}\text { Ekonomik sebeplerden dolayı eğitime erişemeyen başarılı öğrencilere, mali kaynak temini ile ilişkili kampanyalar } \\
\text { konu edilmiştir. }\end{array}$ \\
\hline & 17 & $\begin{array}{l}\text { Güney Afrika eğitim sistemindeki başarısızlık nedenlerinden birisinin ırkçı ve sosyal eşitsizliğe dayanan eylemler } \\
\text { olduğu ele alınmaktadır. Çalışma konusu Eğitim: çok şey yapılmalıydı başlıklıdır. Institute of Race Relation (IRR) } \\
\text { tarafından yapılan bir araştırma ile desteklenen bu habere göre } 2014 \text { yılı metrik sınavı, matematik alanı sonucuna } \\
\text { göre sınava katılanların \%35'i, \%40'ın üzerindeki puan alarak başarı göstermiştir. Ancak bunların \%83,0'ü, Beyaz, } \\
\% 69,7 \text { 'si Hintli, \%46,3'ü Melez ve \%28,5'i Siyahtır. Burada ülke nüfusunun \%79'na karşılık gelen Siyahlar başta } \\
\text { olmak üzere ülkedeki ırksal ve sosyal eşitsizliğe yönelik bir gösterge olduğu ele almıştır. }\end{array}$ \\
\hline & 18 & $\begin{array}{l}\text { Eğitim: Çok şey yapılmalıydı" başlığındadır. Kanaat önderi bir kişi tarafından hazırlandığı bildirilen bu haberin } \\
\text { içeriğinde: Güney Afrika eğitim sistemi ile ilişkili sorun ve öneriler yer bulmuştur. }\end{array}$ \\
\hline
\end{tabular}

Diğer konular başlığındaki kategoride tablo-5'de görüldüğü altı ayrı çalışma konusu vardır. Bunlar; 13, 14, 15, 16, 17 ve 18 kodludur. Bu içerikler özetle: Sınıfların kalabalık olması, Güney Afrika eğitim sisteminde, ırkçı ve sosyal eşitsizliğe dayalı düşük başarı düzeyleri, öğretim programının yeniden tasarımı ihtiyacı, ders araç gereçlere erişim, fiziksel altyapı, okul-aile-çevre etkileşimi, evrensel insani değerler, mali kaynakların çeşitlenmesi gibi hususları konu etmiştir. Ayrıca öğretim sürecinde öğretmene dayanan aksaklıklar ve ekonomik zorlukları olan başarılı öğrencilere kaynak temini gibi hususlar da konu olmuştur.

\section{Çalışma konusu gazeteler, medya okuryazarlığı içerik -tema- ve biçim formu verileriyle analiz edildiğinde elde edilen bulgular nelerdir?}

Çalışma konusu gazete içerikleri, içerik analizi çözümlemesindeki bulgular da dikkate alınarak araştırmacının geliştirdiği medya okuryazarlığı içerik -tema- ve biçim analiz formunun, içerik-tema- bölümüne kayıt edilen verileri tablo-6'da sunulmuştur.

Tablo-6. Çalışma konusu olmuş gazete içeriklerinin; yayın alanı ve biçimi ile gazetenin sunum biçimi tablosu

\begin{tabular}{|c|c|c|c|c|c|c|c|c|c|c|c|c|c|c|c|c|c|c|}
\hline \multirow{3}{*}{ Kategorisi } & \multicolumn{18}{|c|}{ Kategori, çalışma konusunun kodu ve analiz başlıkları } \\
\hline & \multicolumn{5}{|c|}{ A } & \multicolumn{4}{|c|}{$\mathrm{B}$} & \multicolumn{3}{|c|}{$\mathrm{C}$} & \multicolumn{6}{|c|}{ D } \\
\hline & 1 & 2 & 3 & 4 & 5 & 6 & 7 & 8 & 9 & 10 & 11 & 12 & 13 & 14 & 15 & 16 & 17 & 18 \\
\hline \multirow{2}{*}{ Gazetenin yayın alanı türü } & $\mathrm{b}$ & $\mathrm{b}$ & $\mathrm{b}$ & $\mathrm{b}$ & $\mathrm{b}$ & $\mathrm{b}$ & $\mathrm{b}$ & $\mathrm{b}$ & $\mathrm{b}$ & $\mathrm{b}$ & $b$ & $b$ & $b$ & $\mathrm{~b}$ & $b$ & $b$ & $b$ & $\mathrm{~b}$ \\
\hline & \multicolumn{18}{|c|}{ (a): uluslararası gazete, $(b)$ : ulusal gazete, $(c)$ : bölge gazetesi ve $(d)$ : şehir gazetesi } \\
\hline \multirow[b]{2}{*}{ Gazetenin yayın biçimi } & $b$ & $b$ & b & $\mathrm{b}$ & $\mathrm{b}$ & $\mathrm{b}$ & $\mathrm{b}$ & $\mathrm{b}$ & $\mathrm{b}$ & $\mathrm{b}$ & $\mathrm{b}$ & $\mathrm{b}$ & $\mathrm{b}$ & $\mathrm{b}$ & $\mathrm{b}$ & $\mathrm{b}$ & $\mathrm{b}$ & $b$ \\
\hline & \multicolumn{18}{|c|}{ (a): fikir gazetesi ve (b): kitle gazetesi } \\
\hline \multirow{4}{*}{ Gazetenin sunum biçimi } & $b$ & $b$ & $b$ & $b$ & $b$ & $b$ & $\mathrm{~b}$ & $b$ & $\mathrm{~b}$ & $\mathrm{~b}$ & $\mathrm{~b}$ & $\mathrm{k}$ & $\mathrm{b}$ & $b$ & $b$ & $\mathrm{~b}$ & $b$ & $\mathrm{~b}$ \\
\hline & \multicolumn{18}{|c|}{ (a): basılı gazete ve $(b)$ : elektronik gazete } \\
\hline & $a$ & $a$ & $a$ & $a$ & $a$ & $a$ & $\mathrm{a}$ & $\mathrm{a}$ & $\mathrm{a}$ & a & $\mathrm{a}$ & a & $a$ & $a$ & $a$ & $a$ & $a$ & $a$ \\
\hline & & & & & & $\mathrm{h}$ & j & $\mathrm{h}$ & & $\mathrm{h}$ & j & j & & $\mathrm{h}$ & & & & \\
\hline Gazete içeriğinin konusu & & & & & & & & j & j & & & $\mathrm{k}$ & & $\mathrm{j}$ & & $\mathrm{j}$ & $\mathrm{j}$ & $\mathrm{j}$ \\
\hline
\end{tabular}

(a): haber, (b): spor, (c): ekonomi (d): siyasi, e): dış politika, (f): bulmaca, (g): magazin (h): araştırma,

i): köşe yazısı, (j): analiz, (k): reklam ve $(m)$ : yazı dizisi.

Tablo-6'da görüldüğü gibi çalışma konusu gazetelerin tamamı, yayın alanı bakımından; ulusal gazete, yayın biçimi bakımından; kitle gazetesi ve sunum formu bakımından; basılı biçimlidir. Çalışma konularının tamamındaki içerik türü ise haber biçimlidir. Bunun yanında 7, 8, 9, 11, 12, 14, 16, 17 ve 18 kodlu dokuz çalışma konusu; analiz ve 6, 8, 1 ve 14 kodlu dört çalışma konusu araştırma verileri ile desteklenerek sunulan haber biçimlidir. 12 kodlu olan bir çalışma konusu ise haber formunda reklam içeriğine yer verdiği bulgularına ulaşılmıştır. Çalışma konusu kategorilerden biri üniversite öğrenci eylemleri başıılıdır. Bu kategoride beş ayrı çalışma konusu vardır. Bunlar; 1, 2, 3, 4 ve 5 kodludur. Bu çalışma konularında yer alan içeriklerin, içerik analiziyle çözümlendiğinde elde edilen verilerin özetleri tablo-2'de verilmiştir.

Çalışma konusu gazete içerikleri, içerik analizi çözümlemesindeki bulgular da dikkate alınarak araştırmacının geliştirdiği medya okuryazarlığı içerik -tema- ve biçim analiz formunun, biçim bölümüne kayıt edilen verileri tablo-7'de sunulmuştur. 
Tablo-7. Gazete içeriklerinin eleştirel medya okuryazarlığı bağlamında içerik -tema- çözümlemesi

\begin{tabular}{|c|c|c|c|c|c|c|c|c|c|c|c|c|c|c|c|c|c|c|}
\hline \multirow{3}{*}{ Başlığın adı } & \multicolumn{18}{|c|}{ Kategori, çalışma konusu numarası ve var olan özellikleri } \\
\hline & \multicolumn{5}{|c|}{$\begin{array}{c}\text { Üniversite öğrenci } \\
\text { eylemleri }\end{array}$} & \multicolumn{4}{|c|}{ Metrik sınavları } & \multicolumn{4}{|c|}{$\begin{array}{l}\text { Bilişim teknolojisi } \\
\text { temelli çalışma }\end{array}$} & \multicolumn{5}{|c|}{ Diğerleri } \\
\hline & 1 & 2 & 3 & 4 & 5 & 6 & 7 & 8 & 9 & 10 & 11 & 12 & 13 & 14 & 15 & 16 & 17 & 18 \\
\hline Bulunduğu sayfa & 4 & 4 & $\mathrm{k}$ & $\mathrm{k}$ & $\mathrm{k}$ & 5 & $\mathrm{e}$ & $4-5$ & 6 & 7 & $\mathrm{e}$ & 6 & 7 & 8 & 19 & 6 & 6 & 8 \\
\hline $\begin{array}{l}\text { Sayfadaki sütun sayısı } \\
\text { Yeri }\end{array}$ & 6 & 8 & 4 & 4 & 4 & 8 & 8 & 12 & 6 & 6 & 6 & 6 & 6 & 5 & 5 & 8 & 6 & 5 \\
\hline Varsa sayfa başlığı adı & & & & & & $*$ & & & & & $*$ & $*$ & $*$ & $*$ & $*$ & $*$ & & $*$ \\
\hline İçeriğin büyüklüğü & $\mathrm{g}$ & $\mathrm{g}$ & $\mathrm{g}$ & $f$ & $f$ & $\mathrm{~b}$ & $\mathrm{~b}$ & a & $\mathrm{b}$ & $f$ & $\mathrm{~g}$ & $b$ & $\mathrm{~b}$ & $d$ & $\mathrm{~d}$ & $\mathrm{~d}$ & $\mathrm{C}$ & $\mathrm{b}$ \\
\hline Resim-fotoğraf sayısı & 1 & 1 & 1 & 1 & 1 & 2 & 1 & 2 & 1 & 1 & & 1 & 1 & & & 1 & 1 & 1 \\
\hline Yazı fontu -büyük/küçük- & k & $\mathrm{k}$ & k & $\mathrm{k}$ & k & $\mathrm{k}$ & $\mathrm{k}$ & $\mathrm{k}$ & $\mathrm{k}$ & $\mathrm{k}$ & $\mathrm{k}$ & $\mathrm{k}$ & $\mathrm{k}$ & $\mathrm{k}$ & $\mathrm{k}$ & $\mathrm{k}$ & k & $\mathrm{k}$ \\
\hline Dolgu & $\sqrt{ }$ & V & V & & $\sqrt{ }$ & & & $\sqrt{ }$ & $\sqrt{ }$ & $\sqrt{ }$ & & V & V & & $\sqrt{ }$ & $\sqrt{ }$ & & $\mathrm{V}$ \\
\hline Çerçeveli & & & & & & & & & & & $\sqrt{ }$ & & $\sqrt{ }$ & & & & & \\
\hline
\end{tabular}

Yeri: (a): sol üst, (b): sağ üst, (c): orta, (d):sol alt, (e): sağ alt

Bulunduğu sayfa: (k): kapak sayfası, (numaralar): sayfa numarası ve (e ): ek

$(*)$ : (6): News, (11): News, (12): Gauteng, (13): Letter, (14), (16) ile (18) : Politic ve (15): Opinion.

İçeriğin büyüklüğ̈: (a): 4/5, (b): 1/2, (c): $2 / 5,(d): 1 / 3,(g): 1 / 4,(d): 2 / 9,(f): 1 / 6$,

Tablo 7'de de görüldüğü gibi 3, 4 ve 5 kodlu çalışma konuları, kapak sayfasında yer almıştır. Bunlar dışındakiler ya iç sayfalarda ya da ek sayfalarda yer almıştır. Buna göre iki çalışma konusu gazete ekinde yer almaktadır. Bu eklerden biri 8 sayfadadır ve tamamı eğitimle ilişkili içeriğe sahiptir. Bunlar dışında bir tanesi beşinci ve on dokuzuncu sayfada, ikişer tanesi dördüncü, yedinci ve sekizinci sayfalarda, dört tanesi altıncı sayfada yer almıştır. Çalışma konusu içeriklerin yer aldığı sayfaların sütun sayıları, yoğunlukla 6’lıdır. Bunun dışında $4^{\prime} l u ̈, 5^{\prime} l i, 8^{\prime}$ li ve $12^{\prime}$ li sütunlarda kullanılmıştır. Çalışma konularının gazete sayfasının bir yüzünde kapladığı alanın büyüklüğü ise; $6^{\prime}$ sında $1 / 2,4$ 'ünde $1 / 4,3$ 'ünde $1 / 6$, 3'ünde $1 / 3$ ve birinde $2 / 5$ ile birinde $4 / 5^{\prime}$ dir. Çalışma konularının 8 tanesinin bulunduğu sayfanın tematik başlığı vardır. Bu tematik başlıklar: birer tanesinde; Politic, Gauteng ve Opinion, 2 tanesinde News ve 3 tanesinde Letter başıklıdır. Çalışma konularının 12 tanesinde dolgu ve 2 tanesinde metin çerçevesi vardır. Tamamında küçük yazı fontu kullanılmıştır. Gazete içeriklerinin olumlu ve olumsuz yönlerine ilişkin bulgular Tablo 8'de sunulmuştur.

Çalışma konusu gazete içerikleri, içerik analizi çözümlemesindeki bulgular da dikkate alınarak araştırmacının geliştirdiği medya okuryazarlığı içerik -tema- ve biçim analiz formunun, değerlendirme bölümüne kayıt edilen verileri tablo-8'de sunulmuştur.

Tablo-8. Gazete içeriklerinin olumlu ve olumsuz yönleri

\begin{tabular}{|c|c|c|c|c|c|c|c|c|c|c|c|c|c|c|c|c|c|c|}
\hline \multirow{3}{*}{ Kategorisi } & \multicolumn{18}{|c|}{ Kategori, çalışma konusu numarası ve alt kategorisi } \\
\hline & \multicolumn{5}{|c|}{ A } & \multicolumn{4}{|c|}{ B } & \multicolumn{3}{|c|}{$\mathrm{C}$} & \multicolumn{6}{|c|}{ D } \\
\hline & 1 & 2 & 3 & 4 & 5 & 6 & 7 & 8 & 9 & 10 & 11 & 12 & 13 & 14 & 15 & 16 & 17 & 18 \\
\hline \multirow{4}{*}{$\begin{array}{l}\text { İçeriği eleştirel medya } \\
\text { okuryazarlığı bakımından olumlu } \\
\text { mu? }\end{array}$} & & & & & & a & $\mathrm{a}$ & a & a & a & $\mathrm{a}$ & $\mathrm{a}$ & $\mathrm{a}$ & $\mathrm{a}$ & $\mathrm{a}$ & $\mathrm{a}$ & a & $\mathrm{a}$ \\
\hline & \multicolumn{18}{|c|}{ (a): bilgilendiriyor, (b): eğitiyor, (c): eğlendiriyor veya (d): sosyalleştiriyor. } \\
\hline & $\mathrm{d}$ & $d$ & $d$ & $d$ & d & & & & & & & & & & & & & \\
\hline & $\mathrm{e}$ & e & e & e & e & & & & & & & & & & & & & \\
\hline \multirow{6}{*}{$\begin{array}{l}\text { İçeriği eleştirel medya } \\
\text { okuryazarlığı bakımından olumsuz } \\
\text { mu? } \\
\text { /saptırma ve yeni değer dizini } \\
\text { oluşturma gayreti }\end{array}$} & g & g & g & g & g & & & & & & & c & & & & & & \\
\hline & $\mathrm{h}$ & $\mathrm{h}$ & $\mathrm{h}$ & $\mathrm{h}$ & $\mathrm{h}$ & & & & & & & & & & & & & \\
\hline & j & j & j & j & j & & & & & & & & & & & & & \\
\hline & 0 & 0 & 0 & 0 & 0 & & & & & & & & & & & & & \\
\hline & \multicolumn{18}{|c|}{$\begin{array}{l}\text { (a): saptırma, (b): propaganda, (c): reklam (d): tekrar, e): güçlü değerlere gönderme, (f): önyargı, (g): } \\
\text { slogan, (h): yanlı, (i): beslenme imgesi, (j): ırk ve sınıf ayrımı, }(k) \text { : pornografi, }(m) \text { : savaş, }(n) \text { : } \\
\text { kalıplaşmış cinsel kimlikler ve (o): nefret ve şiddet ögeli. }\end{array}$} \\
\hline & $\mathrm{a}$ & $\mathrm{a}$ & $a$ & $\mathrm{a}$ & $\mathrm{a}$ & & & & & & & & & & & & & \\
\hline İçeriğin etkilendiği yer & $b$ & $b$ & $b$ & $b$ & $\mathrm{~b}$ & & & & & & & & & & & & & \\
\hline
\end{tabular}

(a): ekonomi, (b): ideoloji ve (c): politik güç

Tablo 8'de de görüldüğü gibi çalışma konusu gazete içeriklerine, eleştirel medya okuryazarlığı boyutuyla bakıldığında, on üçünün olumlu medya içeri olduğu saptanmıştır. Bu saptamanın farkına varılmasına, açıklanmasına ve değerlendirilmesine yönelik bilinç oluşum süreci şunlara dayanmaktadır: Bu gazete içerikleri eğitim sistemiyle ilişkili değişik konuları gündeme taşımış, bunlarla ilgili varsa tespit edilen sorun ile çözüm önerisi ve tedbirlere yer vermiştir. Bu yönüyle bir anlamda eğitim sistemini yönlendiren, onun düzgün işlemesini sağlayan ve sosyal sistemi desteklemektedir. Gazete içeriklerinde; akıllı okullar projesi, kâğıtsız sınıflar projesi, e-learning çalışmaları başarı hikâyeleri şeklinde konu edilmiştir. Bunun yanında; geri gelmeyen tabletler, kalabalık öğrencili sınıflar, eğitime erişim gibi sorun alanları da gündeme taşınmıştır. Metrik sınavındaki genel ve çok daha derinleşmiş ırksal temeldeki başarısızlığı konusunda göstergelere dayalı haber ve analiz içeriği sunulmuştur. İçerikler, biçim boyutuyla çözümlendiğinde üniversite öğrenci eylemleri hariç hemen hemen her içeriğin iç sayfalarda; bölüm, tema veya bölge başlığında yer bulduğu bulgusuna ulaşılmıştır. Genelde haber, bazen analiz ve köşe yazısı formu kullanılmıştır. Ek olarak verilen çalışma konularının neredeyse tamamı analiz ve araştırma içeriklidir. Başlık ve içerik metinleri küçük harflerle yazılmıştır. Vurgunun güçlenmesi için 
içeriklerin bir kısmında fotoğraflar yer bulmuştur. Sınırlı da olsa renkli vurgu ve doku kullanılmıştır. Gazeteler renkli basılmıştır. Sekiz sayfalık ek olarak verilen içerikte ise sınırlı sayfada grafik ve tablo yer almıştır.

Olumlu medya içerikli olduğu değerlendirilen çalışma konularının; bilgilendirme, eğitme, eğlendirme ve sosyalleşme arasında bilgilendirme amacıyla sunulduğu değerlendirilmektedir. Bunların yanında, 12 kodlu -City Press gazetesi- içeriğinde verilen SMART Learning yazılı logo biçimli, renkli dolgulu bir çerçeve ile sınırlanmış fotoğrafın varlığı görülmüştür. Bu çalışma konusuna; slogan içermesi, konuyu ele alış biçimi, vurgular, bunların tek taraflı ve olumlu açıklamalarla ve başarı hikâyeleriyle sunulduğu görülmüştür. Bu boyutlarıyla olumsuz medya içerikli olduğu, haber görünümlü reklam şeklinde hazırlanıp sunulduğu değerlendirilmiştir. Çalışma konusu gazete içeriklerinin 5 tanesi; tekrar, güçlü değerlere gönderme, slogan içerme, yanlı ırk ve sınıf ayrımı ile nefret ve şiddet öğeli kavramlar etrafında sunulduğu bu yanıyla da olumsuz medya içeriği barındırdığı saptanmıştır.

\section{TARTIŞMA}

Bu çalışmanın bulgu bölümünde, üniversite öğrenci eylemleri kategorisinde yer bulan \#.....mustfall temalı içeriklerin, olumsuz medya içeriği olduğu değerlendirmesi yapılmıştır. Bu değerlendirmesinin detayları ile açıklanması, anlaşıması ve üzerine değerlendirme yapılmasına katkı vermek için bu bölümde derinlemesine doküman analizinde elde edilen verilere göre kavramlar üzerine detaylı tartışmalara yer verilmiştir. Bu amaçla önce Güney Afrika'nın demografik durumu, medya mesajlarının önem derecesi, olumsuz medya mesajlarının tanımlanmasında kullanılan kavramlar, çalışma konusu içeriğinde yer bulan siyasi ve ideolojik taraflar, daha kapsamlı tanımlanmıştır. Daha sonra veya süreçte ise bunlar üzerinde tartışmalar yapılmıştır. Buna göre: Güney Afrika; ulusal, eyalet ve yerel düzeyde üç katmanlı anayasal demokrasi sistemi ile yönetilir. Ulusal düzeyde üç ayrı başkenti ve eyalet düzeyinde ise yedi başkenti ile ülkenin on bir resmi dili vardır. Bunlardan İngilizce ülkenin genelinde, Afrikansca ise Afrikaans (Hollanda) kökenli toplulukların yaşadığı bölgelerde yoğunlukla kullanılan iletişim dili veya ana diller arasındadır. Ülkenin resmi istatistik ajansının, 2018 verilerine göre ülke nüfusu 57,73 milyondur. Güney Afrika'da resmi dillerin, ana dil bağlamında dağılımı, South Africas Goverment, (2019) verileriyle şöyledir. "Zulu (IsiZulu) 24,6\%, Koza (isiXhosa) 17\%, Afrikaans 12,1\%, İngilizce 9,6\%, Sipide (Sepedi) 9,5\%, Setsvana (Setswana) 8,8\%, English (8,3\%), Sisetho (Sesotho) 8,0\%, Songa (Xitsonga) 4,52. Sesvati (Siswati) 2,6\%, Venda (Tshivenda) 2,4\% ve Nidebele (isiNdebele) 1,6\%". Bu veriler ve araştırmacının ülke deneyimi, Güney Afrika'nın heterojen bir toplum yapısına sahip olduğunu söyleme fırsatı vermektedir. Fonksiyonel kuramcılara dayanarak heterojen toplumlarda var olan tartışma ve birbirleriyle çelişen hedefleri, bu tartışma ve çelişkilerin eğitim sistemine sağladığı katkı Özdemir'in, (2014, s.14) çalışmasında; Okulları; yönlendirir, düzgün işlemesini sağlar ve sosyal sistemi destekler şeklinde açıklanmaktadır. Çalışma konusu gazete içeriklerine bu boyutuyla bakıldığında, gazete içeriklerinin temelde olumlu katkı verdiği değerlendirilmektedir.

Medya içerikleri, önemli olsun veya olmasın, medya mecralarında sunulma biçimi bakımında önemsiz iken önemli, önemli iken önemsiz kılınabilir. Bu durum İnceoğlu’nun (2011:128) çalışmasında bir anlamada toplumun neyi ne kadar bilmesi gerektiğine onlar adına karar verme olarak da görülmektedir. Bu boyutuyla gazete içeriklerinin, gazetedeki konumu -yer aldığı sayfa ve sunum biçimi- içeriği önemli veya önemsiz kılmada bir araç olarak kullanılabilir. Buna göre çalışma konusu gazete içeriklerinden, bulgular bölümünde olumlu gazete içeriği olarak ele alınan içerikler, iç sayfalarda yer alırken, \#.....mustfall temalı içeriklerin bir kısmının kapak sayfasında yer bulduğu görülmüştür. Bu durum, bu içeriklerin diğerlerine göre daha önemli bir konuma taşındığı şekliyle değerlendirilmiştir. Pretoria News gazetesindeki içerikte yer alan resimde öğrenci olduğu düşünülen bir genç vardır. Sağ elini yumruk yapmış, baş hizasına kadar kaldırmış ve şapkasında EFF sembolü yer bulmuştur. Ayrıca EFF metinlerdeki içeriklere de konu olmuştur. Bu yönüyle, Ekonomik Özgürlük Savaşçıları (Economik Freedom Fighters-EFF) ne ve kimlerdir? Sorusuna cevap aramak ve eleştirel medya okuryazarlığı boyutuyla daha detaylı çözümleme yapmak, çalışmanın açık ve anlaşılır olmasına katkı vermek için yerinde olacağı değerlendirilmiştir. Economic Freedom Fighters (2018) verilerinden yapılan derlemede: EFF; 28 Temmuz 2013' de kurulmuştur. Marksist-Leninist gelenekten esinlenen bir siyasi partidir. Afrikalı siyahi halkları esas alan milliyetçi bir çizgisi vardır. Kurulduktan sonra, bir yıl içinde 2014 Kasım'da seçimler yapılmış ve bu seçimde \%6,35 oranında oy almıştır. Bu oy oranı ona ülke yönetiminin, ulusal düzeyde temsil edildiği parlamentoda, 400 Milletvekilinin 25 'ini kazandırmıştır. Tüm bunlar \#.....mustfall temalı içerikleri ideolojik temelle kurgulanmış olma eleştirisi yapılmasına bunların ise olumsuz medya mesajı içerdiği görüşünü desteklediği şekli ile değerlendirilmiştir.

Gazete içeriklerindeki \#.....mustfall formlu içerikler sadece eğitim sistemiyle ilişkili değil başka konuları da tema olarak kullanmıştır. Bunlar arasında iktidardaki African National Congress (ANC) partisinin genel başkanı ve ülkenin devlet Başkanı Jacob Zuma'ya yönelik 6 Ağustos 2015'de parayı geri öde anlamına gelen, “\#PayBackTheMoney” ve Zuma gitmeli anlamına gelen "\#ZumaMustFall” temalı gazete içerikleri ve öğrenim ücretsiz olmalı anlamına gelen "\#FeesMustFall” bunlara örnek olarak verilebilir. ANC adlı siyasi parti ve taraftarlarının eleştirildiği veya karşı tarafa konulduğu içeriklerin yanında, EFF adlı siyasi partinin söylemleriyle açıklamalar, medya okuryazarlığı bağlamında yanlı yani olumsuz medya mesajı içerdiği eleştirisinin yapılmasına katkı sunmaktadır.

Ayrıca ülkenin geçmişine dayanan ırksal temelli ayrımcılığı temsil eden (Apertahid) uygulamalarına atıfla üretilen Rhodes yok olmalı "\#RhodesMustFall” temalı içerikler de vardır. Bu içeriğe, farklı temalardaki \#.....mustfall” temalı içeriklerle bir bütün olarak bakıldığında ve medya okuryazarlığı boyutuyla eleştirildiğinde ırk ve sınıf ayrımını destekleyen olumsuz medya içeriği olduğu değerlendirmesin yapmaya katkı vermektedir. 
Üniversite öğrenci eylemlerinin maddi zarar doğuran sonuçları, The News gazetesinin haberinde: 1000 civarında üniversite öğrencisinin eylemi gerçekleştiği, bunun sonucunda \%57'inin R20000 (yaklaşık 1300\$)' \%12'sinin ise R350 000 (yaklaşık $22500 \$$ )'। aşan maddi kayıp oluştu şeklinde açıklanmıştır. Bu içeriğe, farklı temalardaki \#.....mustfall” temalı içeriklerle bir bütün olarak bakıldığında ve medya okuryazarlığı boyutuyla eştirildiğinde nefret ve şiddet ögeli olumsuz medya içerikleri olduğu değerlendirmesinin yapılmasına katkı vermektedir.

Medya mesajlarında propaganda; "anlamlı sembol, söylenti, haber, resim ve toplumsal iletişimin diğer biçimleriyle kamuoyunu etkilemek için gerçek, yarı gerçek ya da yalan bilgilerdir" (Bektaş, 1996, s.153). Propagandanın tanımında yer alan anlamlı söylenti, üniversite öğrenci eylemlerine konu olan \#.....mustfall teması ile ele alınan içeriklerin yukarıdaki çözümlemelere bakıldığında \#.....mustfall kurgusu: \#AfrikaansMustFall, \#feeMustFall, “\#ZumaMustFall ve \#RhodesMustFall gibi değişik formlar yer almaktadır. Buna göre \#.....mustfall anlamlı semboller üzerine kurgulu toplumsal iletişim biçimi olarak kullanılmış olabileceği de değerlendirilmiştir. Bu içeriklerin Afrikalı siyahi halkları esas alan milliyetçi çizgisi ile öne çıkan bir siyasi parti ile özdeşleşmesi; propagandanın özellikle siyasal parti propagandalarında çok kullanılır olması yaklaşımlarıyla uyumludur. Bunun yanında içeriklerde ele alınan temaların; özgürlük gibi toplumların kabul ettiği değer ve duygusal boyutu olduğu da değerlendirilmektedir. Tüm bunların ise bu gazete içeriklerinin eleştirel medya okur yazlığı boyutuyla olumsuz medya içeriği olma ihtimalini güçlendirmektedir.

Bir siyasi partiyi sorunların merkezine koyup, başka bir siyasi parti üzerinden sloganlaştırmak, içerikleri tekrar tekrar sumak ve toplumların öne çıkan güçlü değerlerini medya içeriği yapmak, olumsuz medya mesajı anlamında reklam ifadesi ile de açıklanır. Reklam daha çok; "slogan, tekrar, güçlü değerlere gönderme gibi kavramlar etrafında şekillenir: Dikkat çekmek, ilgi uyandırmak, bir fikri açıklamak, duyguları tetiklemek, arzu yaratmak, eyleme geçirmek ve inananların neyi düşüneceği, hatırlayacağını ve hissedeceğini etkilemek için kullanılabilir" (Bilici, 2014, s.132-137). Slogan "kolay hatırlanıp tekrarlanabilir kısa ve çarpıcı sözdür" (Bilici, 2014, s.132-137). Tekrar: "Ürün ve marka imajı oluşturmak için, farklı formlarda da olsa, bir mesaja uzun süre yer verme işlemidir. Güçlü değerlere gönderme: Vatan sevgisi, milli ve dini değerler, dünya barışı, özgürlük, mutluluk gibi toplumların kabul ettiği değerleri, duygusal boyutta onları etkilemesi için kullanılmasıdır. Nedeni tartışmasız kabul edilen bu tip değerler, özellikle siyasal parti propagandalarında çok kullanıır". Önyargı: "Belirli bir dış grup hakkındaki olumsuz dogmatik kanaatleri içermesi, kanıtlanmadığı halde önceden peşin hüküm verecek şekilde ifadelerin kullanılması, olgunlaşmamış ve herkes tarafından doğru kabul edilmeyen diğer taraftan da bireyden ziyade gruba yönelik bir tepkinin ifadelerde yer bulduğu bir habere yaklaşım biçimidir. Yanlılık ise dengesiz, yanlış ve kısmi olmakla suçlanan haberciliktir" (Stevenson, 2014, s.367).

Bu bağlamda, \#.....mustfall kurgusunun, propaganda, slogan, tekrar ve güçlü değer, nefret söylemi ve şiddet, ırk temelinde ayrım, popüler taraf çıkarma, sansasyon ve mahrem alana müdahale etme ihtimali olan ve ideolojik kodlu içeriklere sahip olabileceğine yönelik eleştiri yapmaya fırsat sunmaktadır. Tüm bunlar üniversite öğrenci eylemleri kategorisindeki içeriklerin; propaganda, reklam, ırk ve sınıf ayrımı, güçlü değerlere gönderme, slogan, nefret ve şiddet ögeli söylem, yanlı, propaganda amaçlı ve manipüle edilmiş içerikler barındırma ihtimali olduğu şekli ile eleştirilmektedir.

\section{SONUÇ VE ÖNERILER}

Gazete içeriklerine konu olmuş, eğitim sistemiyle ilişkili içerikler, dört kategoride toplanmıştır. Bunlar; üniversite öğrenci eylemleri, metrik sınavı sonuçları, bilişim teknolojisi temelli projeler ve diğer konulardır.

Çalışma konularının, on sekizinden, on üçü eğitim sistemiyle ilgili geçmiş, mevcut durum ve gelecek beklentilerini, muhataplarıyla ve zıtlıkları da ele alarak karşılaştırıp paylaştığı değerlendirilmiştir. Bu içeriklerin genel boyutu ile tarafsız, önyargılardan uzak, haber, analiz ve köşe yazısı formunda, fikir ve yorumda zengin içerikler sunduğu değerlendirilmiştir. Bu yönüyle bir anlamda eğitim sistemi yönlendiren, onun düzgün işlemesini sağlayan ve sosyal sistemi destekleyen -bilgilendiren- olumlu medya içerikleri olduğu değerlendirilmiştir. Bunlardan sadece birinde, haber formunda reklam içeriğine de yer verdiği eleştirisi yapılmıştır.

Bunu yanı sıra üniversite öğrenci eylemleri kategorisindeki beş çalışma konusunun ise olumsuz medya içeriği olduğu eleştirisi yapılmıştır. Bu eleştiriler, içeriklerde; tekrar, güçlü değerlere gönderme, slogan, yanlı, ırk ve sınıf ayrımını destekleme, nefret ve şiddet öğeli, yanlı, propaganda amaçlı ve manipüle edilmiş kavramlar etrafında toplanmaktadır.

Medya okuryazarlığı anlayışının temelinde, medya mesajlarındaki dilin eleştirel boyutta okunması, anlaşılması ve farkına varılması vardır. Medya dilinin çözümlenmesinde, öğretim programının amacına uygun ders araç-gereci kullanılmalıdır. Ancak bu tür araç ve gereçler ya yoktur ya tv gibi öne çıkan medya mecralarını önceliğe almaktadır ya da yetersizdir. Bu eksikliğe çözüm üretecek birçok yeni çalışma ve uygulamanın yapılması önerilmektedir.

Bu çalışmada araştırmacının geliştirdiği bu çalışmadaki formun ve uygulama biçiminin, medya içeriğine yönelik; algıları ortaya koymaya, görüşleri tartışmaya açarak; ona yeni anlam katmaya ve bilinç oluşturmaya katkı vereceği düşünülmektedir. Bunu yanında medya öğretim sürecinde sınıf içi uygulamaları zenginleşmeye ve öğretmenin yaptığı rehberliğe de katkı sağlayacağı da beklenmektedir. Bu nedenle bu çalışmada, araştırmacı tarafından kullanılan veri toplama ve çözümleme biçiminin, özellikle medya okuryazarlığı sürecinde; gazete türü medya içeriklerinde eleştirel medya okuryazarlığı temelinde yapılacak çözümlemeler için kullanılması önerilmektedir. Ayrıca bu çözümleme biçimine yönelik birçok eksende daha derinlemesine akademik çalışmaların yapılması ve bu çözümleme biçiminin güncelleştirilip etkinleştirilmesi önerilmektedir. 


\section{Etik Kurul Onay Bilgileri}

Bu çalışmanın hem araştırma hem de yayın başvurusu 2018 yılıdır. Yani bu çalışma 2020 yılından önce yapımıştır. Bu nedenle Etik Kurul Kararı yoktur. Ancak çalışmada Anket, mülakat, odak grup çalışması, gözlem, deney, görüşme teknikleri kullanılarak katılımcılardan veri toplanmamıştır.

\section{KAYNAKÇA}

Anderson, J. (1983). Children's understanding of television: Research on attention and comprehension. Television Literacy And The Critical Viewer. New York: Academic Press.

Antuli, N. (2016, 15 Ocak). Dispute over 0\% pass KZN news. The Newage, s.7.

Aydemir, S. \& Erdamar, G. (2018). Medya okuryazarlı̆̆ı eğitimi alanında yapılan çalışmaların tematik, metodolojik ve istatistiksel yönelimleri. Kastamonu Education Journal. 26 (4), 1155-1166. doi:10.24106/kefdergi.409585.

Bektaş, A. (1996). Kamuoyu. İletişim ve demokrasi (4. baskı). İstanbul: Bağlam Yayınları.

Buckingham, D. (1992). Media education - the limits of a discourse. Journal of Curriculum Studies. 24(4). 297-313.

Bilgin, N. (2006). Sosyal bilimlerde içerik analizi teknik ve örnek çalışmalar (2. baskı). Ankara: Siyasal Kitabevi

Bilici, i. E. (2014). Medya okuryazarlığı ve eğitimi. Ankara: Nobel Yayınları.

Büyüköztürk, Ş. Çakmak, E. K. Akgün, Ö. E. Karadeniz, Ş. \& Demirel, F. (2008). Bilimsel araştırma yönetmeleri. (11. baskı). Ankara: Pagem Akademi. Demirkent, N. (2003). Sayfa sayfa gazetecilik. İstanbul: Dünya Kitapları.

Elma, C. Kesten, A. Dicle, A. N. Mercan, E. Çınkır, Ş. \& Palavan, Ö. (2009). İlköğretim 7. sınıf öğrencilerinin medya ve medya okuryazarlığı dersine ilişkin tutumları. Ondokuz Mayıs Üniversitesi Eğitim Fakültesi Dergisi. 27. 93-113.

Economic Freedom Fighters, (2016, Şubat 08). EFF. <http://effighters.org.za/> (2016, Şubat 08).

Ertürk, D.Y \& Akkor, G. A. (2006). Çocuğunuzu televizyona teslim etmeyin, Ankara: Nobel yayın dağıtım

Goba, N. (2016, 21 Mart). Afrikaans must go, says EFF in Gauteng. The Times, s.4.

Hobbs, R. (2016, Mart 12). Empowerment and protection at the world summit on media for children and youth. <https://mediaeducationlab.com/blog/empowerment-and-protection-world-summit-media-children-and-youth> (2016, Mart 12).

İnceoğlu, M. (2011). Tutum algı iletişim (6. baskı). Ankara: Siyasal Kitapevi.

Madisha. K. (2016, 16 Şubat). Funding the wits missing middle. The Newage, s.5.

Makhetha, T. (2016, 17 Şubat). EFF demands that afrikaans must falll at tuks. Pretoria News, s.1.

Milli Eğitim Bakanlığı, (2009). Medya okuryazarlı̆ı̆ öğretmen kılavuz kitabı. Devlet Kitapları, (2. Baskı). İstanbul: ihlas Gazetecilik.

Mitchley. A. (2016, 10 Şubat). Quality education still unavaliable to many black: survey, The Star, s.8

Mlambo, S. (2016, 4 Şubat). Matric drop out shock. Daily News, s.7.

Morero, D. (2016, 16 Şubat). Education: much to be done, The Newage: Analist, s.14.

Monama, T. (2016, 12 Şubat). Trials and triblations of paperless cassroom. The Star, s.11.

Nzimande, B. (2016, 23 Şubat). Post-school education and training opportunities. The Independent. Thinking, s. Attahment-5.

Özdemir, S. (2014). Türk eğitim sistemi ve okul yönetimi (3. baskı). Ankara: Pagem Akademi Yayınları.

Petersen, C. (2016, 10 Mart). Rhodes must fall exhibit at UCT, The Star, s.8.

Phaladi, B. (2016, 10 Şubat). 12000 tablets missing in Gauteng. The Citizen, s.8.

Prince, L. (2016, 28 Şubat). Guaten's smart school project making progress. City Press, s.10.

Radyo ve Televizyon Üst Kurulu, (2016). Medya Okuryazarlı̆̆ı Araştırması, Ankara: Kamuoyu, Yayın Araştırmaları Ve Ölçme Dairesi Başkanlığı.

South Africas Goverment, (2019, Eylül, 30). Languages. <www.gov.za/about-sa/south-africas-people\#languages>. (2019, Eylül, 30).

Stevenson, N. (2014). Medya kültürleri, sosyal teori ve kitle iletişim. Ankara: Ütopya yayınları

Şahin, M. (2015). Öğretim materyallerinin öğrenme-öğretme sürecindeki işlevine ilişkin öğretmen görüşlerinin analizi. K. Ü. Kastamonu Eğitim Dergisi. 23(3). 995-1012.

Şeylan, S. (2008). Medya okuryazarlığı ders uygulamalarında dünya üzerinde görülen aksaklıklar. Yayınlanmamış Yüksek Lisans Tezi. İstanbul Kültür Üniversitesi, İstanbul.

The Star-leter, (2016, 19 Şubat). Education bill not a blank cheque bussines report. Star Letter, s 7.

The Star, (2016, 10 Mart). EFF student to intensify UNISA protest. The Star, s.1-9.

Toruk, ì. (2008). Üniversite gençliğinin medya kullanım alışkanlı̆̆ı üzerine bir analiz. Selçuk Üniversitesi Sosyal Bilimler Enstitüsü Dergisi. 19. 475488.

UNESCO, (2006). Media education a kit for teacher, students, parents and professionals. France: L'exprimeur

Ülker, M. (2012). Medya okuryazarlığı dersi öğretmen kılavuz kitabının öğretim programı ile tutarılığının değerlendirilmesi. Yayınlanmamış Doktora Tezi. Gazi Üniversitesi, Ankara.

Yüksel, E. (2001). Medyanın gündem belirleme gücü. Konya: Çizgi Kitabevi Yayınları.

Yıldırım, A. \& Şimşek, H. (2018). Sosyal bilimlerde nitel araştırma yöntemleri. (11. Baskı). Ankara: Seçkin Yayıncılık 